Aneta Jegier* (iD https://orcid.org/0000-0003-2492-4876

Akademia Pedagogiki Specjalnej w Warszawie

e-mail: ajegier@aps.edu.pl

\title{
Znaczenie animacji we wspieraniu rozwoju małych dzieci
}

\begin{abstract}
Streszczenie: Małe dzieci chcą poznawać świat, dążąc do nabywania nowych doświadczeń. Są ekspansywne i ciekawe. Do niedawna w żłobkach dominował model opiekuńczy. Nadal można spotkać opiekunów, którzy twierdzą, że w tych placówkach uczy się dzieci jedynie samoobsługi. Obecnie obowiązujące prawo podkreśla równorzędną rolę opieki, wychowania i edukacji w żłobkach. W artykule przedstawiono znaczącą rolę warsztatu pracy opiekunów, jak również opisano zalety wykorzystania animacji w pracy z najmłodszymi na podstawie wyników przeprowadzonych badań. W żłobkach bowiem nie sprawdza się realizacja zajęć z wykorzystaniem modelu szkolnego. Szczególnie ważne jest stymulowanie naturalnej ciekawości dzieci, podążanie za nimi, ale i inspirowanie do działania.
\end{abstract}

Słowa kluczowe: animacje dla dzieci, animator dziecięcy, zabawa dziecięca, koncentracja uwagi, ciekawość świata

\section{Wprowadzenie}

Animacja we wspieraniu rozwoju małego dziecka pełni szczególną rolę, jest bowiem częścią systemu wychowania. Oczywiście, jak pisze Zofia Frączek „Koncepcje wychowania ewoluują i noszą ślady epoki, w której powstały, a wraz ze zmieniającymi się poglądami na wychowanie zmieniają się także oczekiwania stawiane

Aneta Jegier - doktor nauk humanistycznych, adiunkt w Akademii Pedagogiki Specjalnej im. Marii Grzegorzewskiej w Warszawie, w Katedrze Pedagogiki Małego Dziecka. Od trzech lat pełni funkcję kierownika żłobka publicznego w Warszawie. Prezes Stowarzyszenia na Rzecz Wspomagania Rozwoju Dzieci ze Specjalnymi Potrzebami Edukacyjnymi. Zajmuje się problematyką wychowania i kształcenia dzieci w wieku żłobkowym i przedszkolnym oraz innowacjami pedagogicznymi w obszarze relacji dorosły-dziecko. Autorka książek i artykułów dotyczących wspomagania dzieci w dobrym funkcjonowaniu w domu, żłobku i przedszkolu. 
wychowawcom" ${ }^{1}$. W obowiązującej tak zwanej ustawie żłobkowej równoważne znaczenie w działalności żłobków mają opieka, wychowanie i edukacja. Troska o jakość oddziaływań wobec najmłodszych pociąga za sobą konieczność ukazania możliwości korzystnego oddziaływania żłobka na proces wychowawczy i edukacyjny. Tworzenie warunków do optymalnego rozwoju małych dzieci to konieczność sprostania wielu wyzwaniom, na przykład takim, które związane są z budowaniem warsztatu pracy opiekunów. Mimo że w psychologii rozwojowej podkreśla się ogromną rolę pierwszych trzech lat życia dla późniejszego funkcjonowania człowieka, pedagodzy i psycholodzy koncentrują się na strategiach wychowawczych i edukacyjnych realizowanych w przedszkolu i szkole.

Praca z małymi dziećmi wymaga od dorosłych dobrej znajomości rozwoju dzieci, jak również uważności na ich potrzeby. Do żłobków najczęściej przyjmowane są dzieci po ukończeniu 1. roku życia. To czas, gdy dziecięcy rozwój jest napędzany przez ogromną ciekawość. Przyjmuje się, że jest to wrodzone dążenie do poznania obiektów oraz zmienianie otoczenia stosownie do swoich potrzeb. W zakresie tak rozumianej ciekawości małego człowieka występują różnice indywidualne. Jedne dzieci mogą dążyć do poznawania otoczenia zaraz po wykonaniu kilku kroków, inne nieco później. U niektórych dzieci zaspokojenie ciekawości będzie wymagało długiego skupienia uwagi i czasu poświęconego na dany przedmiot, innym wystarczy chwila. W różny też sposób dzieci dążą do poznawania obiektów. Część z nich będzie cechować nieustępliwość w ustaleniu, co można z danym przedmiotem zrobić. Mimo tych różnic najważniejsze jest działanie. Dorosłych nie powinna niepokoić ekspansywność małego dziecka mająca na celu zaspokojenie ciekawości, tylko jej brak². „Wszędobylstwo i ogromna ciekawość świata małego dziecka skutkują rozwojem poznawczym, nabywaniem w niezwykle szybkim tempie wiedzy o otaczającym świecie"

Wychowawcy małych dzieci pełnią szczególną rolę. Według Rousseau ich działania mają uwzględniać naturę dziecka i jego potrzeby. Od wychowawców wymaga się więc tworzenia mądrego i sprzyjającego uczeniu się środowiska zgodnie z poglądem, że wychowywać to pozwolić wzrastać ${ }^{\text {. }}$

Istotne jest pojawienie się w życiu dziecka osoby znaczącej. Wiąże się to z różnymi rodzajami oddziaływań, do których należą:

${ }^{1}$ Z. Frączek, Koncepcja „post-nowego” wychowania jako propozycja i odpowiedź na potrzeby wspótczesnego wychowania, „Annales” 2017, vol. 30(3), s. 8.

${ }^{2}$ K. Appelt, Wiek poniemowlęcy. Jak rozpoznać potencjał dziecka?, [w:] A.I. Brzezińska (red.), Psychologiczne portrety człowieka. Praktyczna psychologia rozwojowa, Gdańskie Wydawnictwo Psychologiczne, Gdańsk 2004, s. 98-102.

3 Tamże, s. 100.

${ }^{4}$ Z. Frączek, dz. cyt., s. 9.

${ }^{5}$ L. Bakiera, B. Harwas-Napierała, Wzory osobowe w rozwoju człowieka, Wydawnictwo Naukowe UAM, Poznań 2016, s. 14-18. 
1. Demonstrowanie konstruktywnych wzorców zachowania. Animator podejmuje czynności, podczas których demonstruje pozytywne zachowania, na przykład cieszy się z danej sytuacji, okazuje ciekawość, dąży do celu.

2. Kontrola. Odziaływanie animatora wyznaczające granice czy kontrolujące przestrzeganie zasad. Jest to związane zarówno z bezpieczeństwem dzieci, jak i z okazywaniem szacunku oraz życzliwości sobie i innym.

3. Inspirowanie. Działanie animatora pobudzające dzieci do działania, co umożliwia kształtowanie procesu uczenia się dzieci.

4. Współdziałanie. $\mathrm{W}$ trakcie zajęć z wykorzystaniem animacji następuje polaryzacja uwagi dorosłego i dzieci na wspólnym działaniu i osiąganych efektach. Wytwarza się więź wynikająca ze wspólnych przeżyć i doświadczeń.

5. Wsparcie. W sytuacji trudnej dla dziecka animator udziela zarówno pomocy w formie naprowadzania na właściwe rozwiązanie, jak i wsparcia emocjonalnego.

Zdaniem Zofii Frączek „Pojmowanie wychowania jako szczególnej relacji pomiędzy prowadzonym i prowadzącym wiąże się z uznaniem, że ludzie wchodzący w społeczne relacje dzielą się na starszych i młodszych, bardziej i mniej doświadczonych, więcej i mniej wiedzących. Prowadzący zna cele i środki oraz motywy swojego działania, które są ukierunkowane na wyprowadzenie podopiecznych ze stanu niewiedzy w sferze społecznej i skierowanie ich na drogę osiągania wytyczonych celów, a także uczynienie ich użytecznymi dla wspólnoty"6.

Jeśli dorosły pochyla się nad dzieckiem i uczestniczy w jego aktywności poznawczej, może wspólnie z nim tworzyć sytuacje i organizować ukierunkowane działanie. Dzięki temu dziecko ma szansę gromadzić nowe doświadczenia i może rozszerzać oraz precyzować czynności umysłowe. W społecznym uczeniu się dziecka, które jest rdzeniem wspomagania jego rozwoju psychoruchowego, uczestniczą mały człowiek i osoba dorosła. Proces ten zawsze rozpoczyna się od ustalenia wspólnego pola uwagi. Dorosły i dziecko swoją uwagę skupiają na tym samym obiekcie. Następnie tworzą wspólne pole działania, czyli realizują czynności związane z tym obiektem. Podczas uczestnictwa we wspólnym działaniu dorosły ukierunkowuje działania malucha tak, aby gromadził on nowe doświadczenia, uwzględniając jego strefę najbliższego rozwoju ${ }^{7}$. Efektami zorganizowanego w taki sposób procesu społecznego uczenia się są: coraz lepsze funkcjonowanie umysłu dziecka oraz poszerzenie wiedzy o sobie, jak również o własnych możliwościach sprawczych. Specyficzne dostrajanie się dorosłego do możliwości dziecka jest warunkiem sukcesu. Sprzyja temu porozumienie w warstwie niewerbalnej (uśmiechy, spojrzenia, czynności czy gesty) i werbalnej (okrzyki

6 Z. Frączek, dz. cyt., s. 8.

7 E. Gruszczyk-Kolczyńska, Wspomaganie małych dzieci w skupianiu uwagi i organizowaniu aktywności poznawczych i wykonawczych, [w:] E. Gruszczyk-Kolczyńska (red.), Wspomaganie rozwoju i wychowywanie małych dzieci. Podręcznik dla rodziców, opiekunów w żłobkach i nauczycieli w przedszkolach, Bliżej Przedszkola, Kraków 2019. 
zadowolenia, słowna zachęta, stwierdzenia) oraz wspólne lub równoległe wykonywanie czynności ${ }^{8}$.

Dostrajanie to zaczyna się, kiedy maluch podchodzi do dorosłego zaciekawiony obiektem, którym ten się zajmuje. Aby zaaranżować wspólne pole uwagi, dorosły musi porozumieć się z dzieckiem $\mathrm{w}$ sprawie wspólnego zajmowania się tym przedmiotem oraz udostępnić go dziecku. Takie wspólne działania dorosły zaczyna tworzyć, zaczynając od czynności, którą dziecko może wykonać samodzielnie, stopniowo jednak rozszerza je o nowe. Dostrajanie się dorosłego do aktywności dziecka w takiej formie pozwala stopniowo, w optymalnej formie i czasie wprowadzać nowe doświadczenia, dzięki czemu dziecko z łatwością może je przyswoić9.

Warunkiem koniecznym we wspomaganiu rozwoju psychoruchowego małych i nieco starszych dzieci jest organizowanie uczenia się na miarę strefy najbliższego rozwoju oraz dostrajanie się dorosłego do aktywności dziecka, w którym należy pamiętać o ważnej roli modelowania oraz naśladownictwa ${ }^{10}$.

\section{Animacje}

Etymologicznie termin animacja pochodzi od łacińskiego słowa anima, co znaczy dusza. Z kolei słowo anime oznacza ożywiać. Zatem animacje w kontekście pracy z drugim człowiekiem definiuje się jako ożywianie ludzi, zachęcanie ich do aktywności, tworzenie, kreowanie, podgrzewanie atmosfery. Animacją nazywa się wszelkie formy aktywizacji i zachęcania do przyjemnego, wspólnego spędzania czasu. W kontekście tak rozumianej animacji animatorem będzie osoba mająca za zadanie skutecznie zaprosić ludzi do takich zajęć, które nie tylko „ożywią", ale też zainspirują, pobudzą, rozśmieszą, sprawią, że człowiek będzie czuł się pozytywnie ${ }^{11}$.

Według innej definicji animacja jest intencjonalnym kierowaniem ludźmi w czasie wolnym przez włączanie ich bezpośrednio do danej aktywności. Skupia ona w sobie takie działania, jak: ożywianie, organizowanie, inicjowanie, instruowanie, zachęcanie, promowanie, pobudzanie, doradzanie. Tak rozumiana animacja ma na celu wzbogacanie czasu wolnego wartościami, dającymi szansę na zaspokojenie potrzeb człowieka, a animator swoją postawą i entuzjazmem ma pobudzić ludzi do udziału w organizowanych zajęciach, które zostały wcześniej (najlepiej przez niego, osobiście) przygotowane $^{12}$.

${ }^{8}$ H. Olechnowicz, Pierwsze kroki wśród ludzi: problemy wychowawcze najwcześniejszego dzieciństwa, Druga Strona - Wydawnictwo IPS, Warszawa 2015.

${ }^{9}$ E. Gruszczyk-Kolczyńska, Wspomaganie..., dz. cyt.

10 Tamże, s. 73-77.

11 J.B. Bączek, T. Misztal, Od amatora do animatora, Stageman, Warszawa 2017, s. 14.

${ }_{12}$ P. Litwicka, Metodyka i technika pracy animatora czasu wolnego, Wydawnictwo Proksenia, Kraków 2010, s. 9. 


\section{Badania własne i ich analiza jakościowa}

Celem badań była analiza znaczenia animacji dla rozwoju małych dzieci poprzez poznanie opinii opiekunów w żłobku (wywiad), jak również poprzez analizę zajęć z wykorzystaniem animacji (obserwacja).

Badania wpisują się w nurt podejścia strukturalnego i procesualnego. To pierwsze dotyczy wymagań stawianych opiekunom jako osobom pełniącym funkcję opiekuńczą, wychowawczą i edukacyjną. Drugie zaś - realizacji przez nich zajęć z podopiecznymi. Uzyskane wyniki mają charakter dość subiektywny, gdyż konstruowane były lokalnie i ograniczały się do jednego środowiska. Jednak zdobyta wiedza może stanowić punkt wyjścia do refleksji nad tym, czy możliwe jest wprowadzenie animacji do zajęć w żłobku, co jest ważne w tym aspekcie oraz jakie zmiany należy zainicjować dla wzbogacenia warsztatu pracy opiekunów jako animatorów, aby skutkowało to jeszcze lepszymi warunkami rozwoju dla najmłodszych podopiecznych.

Poniżej przedstawiono rezultaty wywiadu z opiekunami jednego z warszawskich żłobków publicznych. Wypowiadali się oni na temat kompetencji opiekuna jako animatora zajęć $\mathrm{z}$ najmłodszymi, różnic, jakie widzą w realizacji zajęć, a także możliwości zastosowania animacji w pracy z dziećmi.

\section{Wywiad z opiekunami w żłobku}

\section{Kompetencje animatora}

Animator jest określany przez wypowiadających się opiekunów jako pogodny duch, który cechuje się gotowością do nawiązywania kontaktów, przyjaznym stosunkiem do otoczenia, umiejętnością emocjonalnego angażowania się. Wykazuje on entuzjazm w działaniu, inicjatywę, elastyczność w stosowaniu różnych rozwiązań, łatwo nawiązuje kontakty z ludźmi. Opiekun w roli animatora powinien być osobą śmiałą, dobrze zorganizowaną, energiczną oraz odpowiedzialną. Równocześnie od animatora oczekuje się dużej cierpliwości oraz opanowania umiejętności szybkiego łagodzenia ewentualnych konfliktów.

Opinie głoszone przez opiekunów są zbieżne z podanymi przez Patrycję Litwicką, według której cechy pożądane na stanowisku animatora to: poczucie odpowiedzialności, pewność siebie, inteligencja, kreatywność, cierpliwość, radość i empatia, entuzjazm i zapał, elastyczność, poczucie humoru ${ }^{13}$.

Opiekun w roli animatora powinien znać zabawy dostosowane do możliwości zróżnicowanej grupy dziecięcej, od niemowlęcej do starszego przedszkolaka. Powinien specjalizować się w obszarach: sensorycznym, muzycznym, plastycznym, tanecznym, eksperymentów dla dzieci. Konieczne jest przy tym dbanie o bezpieczeństwo dzieci.

\footnotetext{
${ }^{13}$ Tamże, s. 9-14.
} 
Badani określali animatora jako pasjonata dawania radości dzieciom, niesamowity wulkan energii, dla którego uśmiech i radość są najważniejsze. Osoba pracująca w tym zawodzie ma za zadanie dostarczyć najmłodszym rozrywki, jednocześnie wspierając ich rozwój, powinna wiedzieć, jak do dobrej zabawy przemycić elementy edukacji.

\section{Znaczenie animacji dla dzieci}

Małe dzieci bawią się na serio, animator podąża za nimi, co oznacza, że musi im pokazać to, co leży w kręgu ich zainteresowania. Tak małe dzieci interesują fakty, otaczająca je rzeczywistość, coś, co mogą poznawać. Są zafascynowane zielenią trawy czy gładkością wypolerowanego kamyka. Maluchy z ciekawością będą odnajdywać zieleń wokół siebie, poznawać jej różne odmiany. Będą sprawdzać, czy zielone jabłko smakuje tak jak zielony ogórek. Dziecko chce to poznać, dowiedzieć się, zbadać tę pozornie zwyczajną rzecz, używając wszystkich zmysłów. I to my dorośli mamy mu to pokazać. Jeśli jeszcze na zajęciach rozdamy dzieciom plastikowe nożyki i pozwolimy zrobić sałatkę owocową, uwaga wszystkich dzieci przez długi czas będzie skupiona na zadaniu.

Pod koniec wieku żłobkowego, czyli w najstarszej grupie, animacje wraz z rozwojem dziecka wkraczają na inny poziom. Animator ma większe pole do działania i może przenieść dziecko w umowny świat. Opiekun oprócz dekoracji tworzy ten świat sobą, wyrusza w podróż razem z dziećmi. Oprowadza po królestwie, przedstawia znane dziecku z bajek księżniczki, rycerzy. Te postacie tam są, mówią do dziecka, sala zabaw nie jest już znaną dziecku salą zabaw, a zamienia się w prawdziwe królestwo.

Z wypowiedzi opiekunów wynikało wyraźnie, że nauczyciel, animator, opiekun podczas zajęć z wykorzystaniem animacji ma podążać za dzieckiem, rozumieć jego potrzeby i na nie odpowiadać, poruszać się w strefie najbliższego rozwoju, dać dzieciom szansę poznawać otaczający je świat w sposób przyjazny i bezpieczny.

\section{Czym różni się animacja od zwykłych zajęć w żłobku?}

Animacje to rodzaj zajęć, gdzie przygotowany scenariusz jest swoistym zarysem tego, co się wydarzy. Podczas zajęć prowadzący pozostaje cały czas w interakcji z dziećmi, proponując poszczególne zabawy, jednocześnie podąża za dziecięcą ciekawością. W trakcie animacji wiele zależy od dzieci, jednak animator musi stale czuwać, czasem powiedzieć stop, a niekiedy zmienić zajęcia tak, jak proponują dzieci. Animacje są wyjątkowe dlatego, że prowadzący wspólnie z dziećmi przeżywa, odkrywa, poznaje i tworzy.

Animacje dla dzieci proponowane w żłobku to organizowane przez opiekunów aktywności, które pobudzają ciekawość dziecka do poznawania nowych rzeczy, aktywizują je, pozwalają mu być ważnym podczas zajęć. Animator prowadzi dziecko przez daną aktywność, jednocześnie uczestnicząc w niej razem z dzieckiem i podążając za nim. Zaraża małego człowieka swoim zaangażowaniem, radością, uśmiechem i energią. 
Zdaniem opiekunów animacja różni się od zwykłych zajęć realizowanych w żłobku zarówno planowaniem, jak i przebiegiem. Tak zwane zwykłe zajęcia są rozplanowane dość szczegółowo w scenariuszu. Oczywiście w trakcie zajęć możliwe są modyfikacje, ale znający grupę opiekun tak planuje zajęcia, żeby nie było zakłóceń. W przypadku animacji scenariusz to tylko zarys zajęć, reszta zależy od inicjatywy, ciekawości i dziecięcej uwagi.

W animacji, jak twierdzą badani, bardzo ważne są entuzjazm i kreatywność prowadzącego. Dużą trudnością jest konieczność łączenia dwóch ról: przewodnika i podążającego za dzieckiem. Także konieczność zaoferowania dziecku możliwości własnej inwencji, wkładu w zajęcia jest problemem, ponieważ nie każdy opiekun ma umiejętność stawiania granic i wówczas pojawia się ryzyko przejęcia prowadzenia zajęć przez dzieci.

Celem badań była analiza możliwości wykorzystania animacji do poznawania przez małe dzieci obiektów o różnorodnych właściwościach. Postawiono następujące problemy badawcze:

1. Jakie są możliwości wykorzystania animacji w żłobku?

2. Jakie trudności mogą wystąpić podczas zastosowania animacji w pracy z małymi dziećmi?

3. Jakie wyzwania stoją przed opiekunem wykorzystującym animację w codziennej pracy?

W realizacji badań posłużono się całościową obserwacją uczestniczącą, jak również wywiadem z opiekunkami w żłobku.

\section{Obserwacja zajęć - analiza i wnioski z badań}

Zajęcia przeprowadzono w żłobku publicznym w Warszawie, w średniej grupie liczącej 19 dzieci w wieku 20-28 miesięcy. W związku z tym, że dzieci w tym wieku chcą poznawać świat wszystkimi zmysłami, animacje miały na celu umożliwienie dzieciom poznania obiektów o różnorodnych właściwościach właśnie w ten sposób.

Fabułę animacji realizowała pacynka, która pokazywała dzieciom, co najbardziej lubi. Pacynka pełniła również funkcję przedmiotu koncentrującego uwagę dzieci na animatorze, była kimś magicznym, interesującym.

Scenariusz animacji był tworzony na zasadzie ścieżki edukacyjnej - wyodrębnionych „stacji”, na których znajdowały się określone obiekty. Do każdej stacji przypisano proponowane aktywności, mając jednocześnie na uwadze fakt, że dzieci dany obiekt mogą odebrać w inny sposób niż zakładany. Założenie było takie, aby prowadzić dzieci przez ścieżkę, ale także podążać za ich ewentualną inwencją własną (dla animatora ważne jest, aby wzbudzić dziecięcą ciekawość, jak również kreatywność, dlatego sukcesem zajęć jest sytuacja, gdy dzieci wychodzą z własnymi propozycjami).

Czas prowadzenia animacji był uwarunkowany planem dnia w żłobku, jednak długość zajęć była zależna od zainteresowania dzieci. Kierowano się także regułą, aby 
dzieci zostawić z pewnym niedosytem i brać pod uwagę stopień ich męczliwości. Dlatego zgodnie z założeniami animacji nie przewidywano sztywnych ram czasowych, a jedynie prawdopodobny czas trwania zajęć (25 minut).

\section{Zajęcia z wykorzystaniem animacji w grupie żłobkowej}

Opiekunka przywitała się z dziećmi i przedstawiła pacynkę. Następnie pacynka kierowana przez opiekunkę przedstawiła dzieciom plan zajęć. Potem zaprosiła dzieci w podróż po różnych krainach. Pierwsza kraina to „Bąbelkowy raj”. W części sali do podłogi przymocowana została folia bąbelkowa. Opiekunka wraz z pacynką sprawdzała, jakie dźwięki wydaje folia podczas chodzenia, czy przyjemnie jest chodzić po niej w samych skarpetkach, i zachęcała dzieci do działania, do mocnego uderzania dłońmi, tupania i przebijania bąbelków dłońmi, stopami.

Druga kraina to „Kamienista wyspa”. Na wykładzinie rozsypano nieduże kamyki. Pacynka zachęcała dzieci do przejścia po kamykach, a następnie do zebrania kamyków do pojemnika. Opiekunka po zamknięciu pojemników nakłaniała chętne dzieci do potrząsania nimi. Tworzono muzykę.

Trzecia kraina to „Wyspa pełna trawy”. Na podłodze została przymocowana rolka trawy. Dzieci mogły po niej chodzić, dotykać jej, ustalać, jaki ma kolor, jaka jest w dotyku. Następnie pacynka zapraszała do chwili relaksu. Chętni stawali na trawie, przeciągali się, kładli, nasłuchiwali, czy gdzieś przelatuje mucha.

Na koniec zajęć pacynka pożegnała się z dziećmi, obiecując, że jeszcze je odwiedzi, żeby wspólnie wybrać się w kolejną podróż.

\section{Wnioski z obserwacji}

Zajęcia trwały 40 minut. Uczestniczyły w nich oprócz dzieci cztery opiekunki. Jedna prowadziła zajęcia i miała w ręku pacynkę, trzy pozostałe przebywały wśród dzieci, a w zależności od potrzeby usuwały się na bok. Już w chwili pojawienia się pacynki wszystkie dzieci skoncentrowały na niej uwagę i śledziły ją wzrokiem. Mimo że część dzieci w tej grupie z obawą podchodzi do nowych sytuacji, żadne dziecko nie płakało. Pacynka witała się z każdym dzieckiem, ale troje z nich nie chciało dotknąć pacynki i schowało rękę za siebie lub cofnęło się, unikając kontaktu. Opiekunka nie nalegała na przywitanie się z pacynką. Następnie dzieci podążały za opiekunką z pacynką do pierwszej stacji. Dwoje dzieci trzymało za ręce pozostałe opiekunki, jedna dziewczynka chowała się za panią. Gdy grupa zaczęła poznawać folię bąbelkową w pierwszej krainie, tych troje dzieci nie oderwało się od opiekunek, ale bacznie obserwowało, co się dzieje. Z kolei do kamyków, zachęcone przez panie, podeszły samodzielnie. Wszystkie dzieci naśladowały to, co robi opiekunka z pacynką, a niektóre próbowały wymyślać swoje rozwiązania, jak na przykład chodzenie po folii na bosaka, uderzanie 
w nią kapciem, siadanie na folii. Dopiero po wypróbowaniu różnych możliwości dzieci były gotowe, żeby przejść do kolejnej krainy.

W ostatniej krainie opiekunka musiała zareagować na fakt wyrywania trawy przez jednego z chłopców. Dzięki temu, że zrobiła to stanowczo, inne dzieci nie naśladowały kolegi. Poza tym opiekunka szybko przeniosła uwagę dzieci na trawę, odnosząc spodziewany efekt. Dzieci były zaciekawione i kreatywne, z chęcią uczestniczyły we wszystkich relaksacyjnych propozycjach pacynki i same wymyślały sposoby używania miękkiego trawiastego podłoża.

Dzieci były zainteresowane samą pacynką, jak i przygotowaną dla nich ścieżką edukacyjną. Do końca zajęć pozostały zainteresowane poznawaniem przygotowanych dla nich obiektów. Udało się zaciekawić wszystkie dzieci, nawet te, które w „Zwykłych” zajęciach nie chcą brać udziału, pozostając gdzieś poza grupą. Dzieci podczas zajęć z wykorzystaniem animacji miały szansę doświadczyć czegoś, co nie jest dla nich na co dzień dostępne. Wzbudziło to ich zainteresowanie i chęć poznawania oraz kreowania nowych sytuacji.

\section{Podsumowanie - zalecenia dla praktyki pedagogicznej}

Przeprowadzone w żłobku zajęcia pokazują, że da się z powodzeniem przeprowadzić animacje z dziećmi do lat trzech. Dzieci chętnie podążają za dorosłym, jednocześnie wykazując się własną inicjatywą. Jeśli do etapu rozwojowego małych dzieci w odpowiedni sposób dobierzemy materiały, to poprzez animację możemy pomóc dzieciom poznawać otaczający nas świat. Należy jednak pamiętać, że więcej nie zawsze znaczy lepiej, dlatego w pracy z małymi dziećmi trzeba poświęcić dużo czasu na zaspokojenie przez nie ciekawości poznawczej i wzbudzenie inwencji w związku z nowo nabytą wiedzą.

Odpowiedzialność za jakość pracy edukacyjnej spoczywa na opiekunach. Budowanie swojego warsztatu pracy, przezwyciężanie trudności oraz własnych słabości i lęków może skutkować oddziaływaniami edukacyjnymi na wysokim poziomie. W tok aktywności o charakterze edukacyjnym znakomicie wpisują się zajęcia $\mathrm{z}$ wykorzystaniem animacji. Pozostaje otwarte pytanie, które zadała Katarzyna Sadowska „[...] czy jednak każdy opiekun [...] jest w stanie zindywidualizować proces oddziaływań edukacyjnych i efektywnie współtworzyć z dzieckiem proces jego kształcenia?"14. Codzienność żłobkowa pokazuje, że jest coraz więcej opiekunów, którzy doskonalą swój warsztat pracy i podejmują wyzwania, między innymi takie, jak korzystanie z animacji. Dzięki tym dobrym praktykom w żłobkach tworzone są warunki do poznawania świata i samego siebie przez małych podopiecznych.

${ }^{14}$ K. Sadowska, Wczesnodziecięca edukacja w żłobku. Obraz i postrzeganie, Wydawnictwo Naukowe UAM, Poznań 2019, s. 180. 


\title{
Bibliografia
}

Appelt K., Wiek poniemowlęcy. Jak rozpoznać potencjał dziecka?, [w:] A.I. Brzezińska (red.), Psychologiczne portrety człowieka. Praktyczna psychologia rozwojowa, Gdańskie Wydawnictwo Psychologiczne, Gdańsk 2004.

Bakiera L., Harwas-Napierała B., Wzory osobowe w rozwoju człowieka, Wydawnictwo Naukowe UAM, Poznań 2016.

Bączek J.B., Misztal T., Od amatora do animatora, Stageman, Warszawa 2017.

Frączek Z., Koncepcja „post-nowego" wychowania jako propozycja i odpowiedź na potrzeby współczesnego wychowania, „Annales” 2017, vol. 30(3).

Gruszczyk-Kolczyńska E., O społecznym uczeniu się preferowanym przez dzieci $i$ dziecięcej ciekawości, bez której niemożliwe jest wspomaganie rozwoju umysłowego maluchów, [w:] E. Gruszczyk-Kolczyńska (red.), Wspomaganie rozwoju i wychowywanie małych dzieci. Podręcznik dla rodziców, opiekunów w żłobkach i nauczycieli w przedszkolach, Bliżej Przedszkola, Kraków 2019.

Gruszczyk-Kolczyńska E., Wspomaganie małych dzieci wskupianiu uwagi i organizowaniu aktywności poznawczych i wykonawczych, [w:] E. Gruszczyk-Kolczyńska (red.), Wspomaganie rozwoju i wychowywanie małych dzieci. Podręcznik dla rodziców, opiekunów w żłobkach i nauczycieli w przedszkolach, Bliżej Przedszkola, Kraków 2019.

Gruszczyk-Kolczyńska E., Zielińska E., Wspomaganie dzieci w rozwoju do skupiania uwagi i zapamiętywania, WSiP, Warszawa 2005.

Litwicka P., Metodyka i technika pracy animatora czasu wolnego, Wydawnictwo Proksenia, Kraków 2010.

Olechnowicz H., Pierwsze kroki wśród ludzi: problemy wychowawcze najwcześniejszego dzieciństwa, Druga Strona - Wydawnictwo IPS, Warszawa 2015.

Sadowska K., Wczesnodziecięca edukacja $w$ żłobku. Obraz i postrzeganie, Wydawnictwo Naukowe UAM, Poznań 2019.

\section{The importance of activities in supporting young children's development}

\begin{abstract}
Young children want to discover the world, striving to gain new experiences. They are expansive and curious. The care model has dominated in nurseries until recently. We can still come across childminders who think that children should only be taught self-care in nurseries. Current law emphasises the equal role of care, upbringing and education in nurseries. In this article the important role of the work of childminders is presented and the advantages of using activity in work with children, based on conducted research, is presented. In nurseries, conducting classes using the school model doesn't work well. It is really important to use children's natural curiosity, following them, but also inspiring them to act.
\end{abstract}

Keywords: activities for children, childminder, children's play, attention span, curiosity about the world 


\section{About the Author}

Aneta Jegier - Doctor of Humanities, assistant professor at the Maria Grzegorzewska University in Warsaw, Centre of Young Children's Pedagogy. For three years she has been the manager of a public nursery in Warsaw. She is President of the Association for Supporting the Development of Children with Special Educational Needs. She deals with the issues of upbringing and education of children of nursery and preschool age and pedagogical innovations in the area of adult-child relations. She is the author of books and articles on helping children to function well at home, at nursery and at kindergarten. 